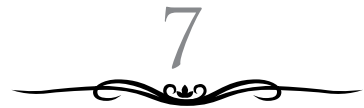

\title{
ANALISIS LAYANAN PERPUSTAKAAN IAIN PURWOKERTO MENURUT STANDAR AKREDITASI PERPUSTAKAAN PERGURUAN TINGGI
}

\author{
Indah Wijaya Antasari \\ IAIN Purwokerto, Jawa Tengah, Indonesia \\ indahbeji@gmail.com
}

\begin{abstract}
University library accreditation is a need. It acts as quality assurance of the library and supports the university development. The accreditation covers nine components, i.e.; Service, Cooperation, Collection, Material Organization, Human Resources, Physical Supports, Funding, Library Management, and Library Collection Maintenance. Service holds highest mark among them, that is 20 out of $100 \%$ by 12 key indicators under service aspects. This research assesses to what extent is IAIN Purwokerto able to prepare library accreditation based on service analysis. Employed quantitavedescriptive approach of library assesment based on standart of university library, the result projects that IAIN Purwokerto is able to get 39 out of 60 points. Even though, it has potency to get 52 points under service assessment. This potency could come from daily opening, weekly opening, members percentage over total students, member percentage over lecturers and university staff, promotion varieties, yearly promotion event, and literacyinformation activity.
\end{abstract}

Keywords: Accreditation, Service, Quality, University Library 


\begin{abstract}
Abstrak
Akreditasi perpustakaan bagi perpustakaan perguruan tinggi sudah menjadi kebutuhan. Akreditasi perpustakaan perguruan tinggi meliputi 9 (Sembilan) komponen yaitu: layanan, kerjasama, koleksi, pengorganisasian bahan perpustakaan, sumber daya manusia, gedung/ruang sarana prasarana, anggaran, manajemen perpustakaan, dan perawatan koleksi perpustakaan. Dari sembilan komponen tersebut, komponen layanan mempunyai mempunyai nilai bobot paling tinggi yaitu 20 (dari 100\%) dengan 12 indikator kunci (aspek layanan). Penelitian ini menggali sejauh mana perpustakaan IAIN Purwokerto dapat menyiapkan diri untuk mengikuti penilaian akreditasi perpustakaan perguruan tinggi dari aspek layanan. Menggunakan pendekatan kuantitatif deskriptif, penelitian ini menunjukkan bahwa perkiraan nilai yang diperoleh dari komponen layanan di perpustakaan IAIN Purwokerto menurut standar akreditasi perpustakaan perguruan tinggi adalah 39 (dari total nilai 60). Namun sebenarnya perpustakaan IAIN Purwokerto berpotensi untuk mendapatkan nilai 52 untuk komponen layanan. Potensi kenaikan nilai ini berasal dari aspek: jam buka perpustakaan perhari, jam buka perpustakaan perminggu, persentase jumlah mahasiswa yang menjadi anggota, persentase dosen dan tenaga kependidikan yang menjadi anggota, jenis promosi yang dilaksanakan, jumlah promosi perpustakaan pertahun, dan kegiatan literasi informasi.
\end{abstract}

Kata Kunci: Akreditasi, Layanan, Kualitas, Perpustakaan Perguruan Tinggi

\title{
A. Pendahuluan
}

Akreditasi adalah proses jaminan mutu yang dikendalikan oleh standar, kebijakan dan prosedur ${ }^{1}$. Dalam hal ini lembaga yang akan diakreditasi dapat mempelajari standar, kebijakan dan prosedur yang ditetapkan oleh lembaga yang berwenang

1 Sulistyo-Basuki,Akreditasi perpustakaan perguruan tinggi. https:// sulistyobasuki.wordpress.com/2013/10/27/akreditasi-perpustakaanperguruan-tinggi/ (diakses 9 September 2016) 
memberikan akreditasi, untuk kemudian diaplikasikan. Jadi jika sebuah perpustakaan ingin diakreditasi, maka perpustakaan tersebut harus memenuhi standar yang telah ditetapkan.

Akreditasi perpustakaan di perguruan tinggi sudah layak untuk dijadikan kebutuhan bagi perpustakaan-perpustakaan perguruan tinggi di Indonesia. Walaupun belum ada atau tidak ada sanksi apapun bagi yang tidak mengajukan akreditasi ini, namun manfaat positif akreditasi perpustakaan dapat menunjang perguruan tinggi dimana perpustakaan itu bernaung. Jika akreditasi perpustakaan sudah didapatkan (terutama dengan nilai A), maka akanmenunjang perguruan tinggi tersebut saat ada akreditasi prodi atau akreditasi institusi misalnya yang akan melibatkan perpustakaan didalamnya.

Menurut Sulistyo-Basuki ${ }^{2}$ secara umum tujuan akreditasi adalah:

1. Memperbaiki lembaga yang diakreditasi; bila yang diakreditasi adalah perguruan tinggi maka akreditasi bertujuan memperbaiki perguruan tinggi. Begitu pula bila yang diakreditasi adalah perpustakaan, maka tujuannya untuk memperbaiki perpustakaan. Jika hasil akreditasi menunjukkan masih kurang memenuhi standar, maka perpustakaan diberi kesempatan untuk memperbaiki.

2. Meningkatkan standar profesi. Profesi dikaitkan dengan pendidikan, sehingga akreditasi untuk lembaga pendidikan tinggi bertujuan meningkatkan mutu lulusannya serta menjamin mutunya.

3. Memberikan informasi bagi umum. Masyarakat dapat mengetahui mana lembaga perguruan tinggi yang memperoleh akreditasi. Hal ini dapat mempengaruhi animo masyarakat untuk mendaftar di perguruan tinggi tersebut.

${ }^{2}$ Sulistyo-Basuki,Akreditasi perpustakaan perguruan tinggi. https:// sulistyobasuki.wordpress.com/2013/10/27/akreditasi-perpustakaanperguruan-tinggi/ (diakses 9 September 2016) 
4. Memudahkan perpindahan dari sebuah perguruan tinggi ke PT lainnya karena ada satuan kredit semester (SKS) yang dapat ditransfer. Bila dua perguruan tinggi dengan program studi yang sama sudah terakreditasi dengan hasil memuaskan, maka transfer satuan kredit antara satu program studi dengan program studi sejenis dapat dilakukan tanpa perlu ada ketentuan baru.

Perpustakaan IAIN Purwokerto sebagai bagian dari perpustakaan perguruan tinggi tersebut merasa perlu untuk mencapai akreditasi yang baik. Nilai Akreditasi yang didapatkan diharapkan akan memicu perbaikan semua bagian, bukan sekedar formalitas hitam diatas putih saja. Kompleksnya aspek yang dinilai dalam akreditasi ini membuat kita harus membuat tahapantahapan pembenahannya. Adapun komponen layanan yang mempunyai porsi nilai terbesar dalam penilaian akreditasi tersebut dianggap mempunyai posisi yang strategis dalam perpustakaan. Oleh karena itu dirasakan perlu untuk membuat analisis layanan di Perpustakaan IAIN Purwokerto menuju akreditasi perpustakaan perguruan tinggi.

Jenis penelitian ini kuantitatif, dengan pendekatan deskriptif evaluatif. Penelitian kuantitatif memfokuskan kajian pada faktor-faktor khusus atau tertentu yang mempengaruhi terjadinya gejala sosial, tidak membahas semua faktor secara umum. ${ }^{3}$ Penelitian evaluasi dapat dinyatakan sebagai evaluasi, namun dalam hal ini juga dapat dinyatakan sebagai penelitian. Jika sebagai evaluasi berarti hal ini merupakan bagian dari proses pembuatan keputusan, produk dengan standard program yang ditetapkan. Jika evaluasi sebagai penelitian berarti akan berfungsi untuk menjelaskan fenomena. Ada dua jenis penelitian evaluasi yaitu: penelitian evaluasi formatif yang menekankan pada proses dan penelitian sumatif yang menekankan pada produk. ${ }^{4}$

${ }^{3}$ Nanang Martono. Metode Penelitian Kuantitatif: Analisis Isi dan Analisis Data Sekunder Edisi Revisi. Jakarta: Rajawali Press, 2011. hlm23

4 Riduwan. Belajar Mudah Penelitian untuk Guru Karyawan dan Peneliti Pemula. Bandung: Alfabeta, 2013.hlm 53 
Penelitian ini dilakukan dengan menggali data-data yang ada di perpustakaan IAIN Purwokerto (dokumentasi), sekaligus melakukan wawancara (dengan bagian akademik dan kepala perpustakaan IAIN Purwokerto) dan observasi langsung dilapangan karena peneliti adalah bagian dariSDM di perpustakaan IAIN Purwokerto. Menggunakan pendekatan deskriptif evaluatif didasarkan standar pada instrumen akreditasi perguruan tinggi yang ditetapkan Perpustakaan Nasional RI. Hal ini dimaksudkan untuk mengoreksi sejauhmana kesiapan perpustakaan IAIN Purwokerto mengikuti penilaian akreditasi perpustakaan ini khusunya dari komponen layanan perpustakaan.

Penelitian ini menggunakan standar akreditasi perpustakaan perguruan tinggi yang telah ditetapkan oleh Perpustakaan Nasional Indonesia. Analisis data yang digunakan adalah analisis data kuantitatif, yaitu data yang disajikan dalam bentuk angka-angka. Instrumen jawaban dinilai dengan skala sebagai berikut:

1. Jawaban a diberi bobot nilai 5

2. Jawaban b diberi bobot nilai 4

3. Jawaban c diberi bobot nilai 3

4. Jawaban d diberi bobot nilai 2

5. Jawaban e diberi bobot nilai 1

\section{B. Pembahasan}

\section{Layanan Perpustakaan}

Perpustakaan perguruan tinggi, sebagai sebuah institusi, agar kualitasnya terukur, maka perlu dilakukan penilaian (akreditasi) terhadap penyelenggaraannya. Suatu penilaian perpustakaan perguruan tinggi oleh lembaga independen yang didasarkan pada suatu acuan penilaian yang bersifat objektif dan transparan kiranya akan menjawab tingkat kualitas perguruan tinggi ${ }^{5}$. Akreditasi perpustakaan perguruan tinggi diukur dengan instrumen yang sudah ditetapkan oleh Perpustakaan

5 Paulus Suparmo. Menggagas Kualitas Perpustakaan Perguruan Tinggi. VISI PUSTAKAVol. 14, No. 3, (Desember 2012). hlm 51 
Nasional RI. Ada 9 (sembilan) komponen penilaian yang terdiri dari Layanan, Kerjasama, Koleksi, Pengorganisasian Bahan Perpustakaan, Sumber Daya Manusia, Gedung/ruang Sarana Prasarana, Anggaran, Manajemen Perpustakaan, dan Perawatan Koleksi Perpustakaan

Kualitas penyelenggaraan perpustakaan banyak ditentukan oleh baiktidaknyalayanan perpustakaan terhadap pemustaka ${ }^{6}$ Salah satu kegiatan utama atau jasa utama perpustakaan adalah jasa sirkulasi ${ }^{7}$. Komponen layanan mempunyai nilai paling tinggi yaitu 20 (dari 100\%). Adapun aspek layanan yang diukur ada 12 (dua belas) yaitu jam buka perpustakaan perhari, jam buka perpustakaan perminggu, sistem peminjaman buku, persentase jumlah mahasiswa yang menjadi anggota perpustakaan, persentase jumlah dosen dan tenaga kependidikan yang menjadi anggota perpustakaan, jumlah rata-rata buku yang dipinjam perbulan, jenis promosi yang pernah dilaksanakan, jumlah promosi perpustakaan pertahun, pelayanan berbasis TIK, literasi informasi, otomasi perpustakaan dan layanan yang diberikan perpustakaan.

Layanan yang dimaksud dalam artikel ini dengan indikator kunci berjumlah 12 lebih condong kepada layanan pengguna. Adapun tugas keprofesian berkaitan dengan layanan peminjamanterdiri dari ${ }^{8}$ :

a. Menyusun peraturan peminjaman

b. Meminda dan menyunting peraturan

c. Merancang formulir dan catatan

d. Mengawasi koleksi buku tandon

e. Menyiapkan laporan statistik

f. Menangani kebutuhan pengguna

${ }^{6}$ Muh.Syarif Bando dkk.Petunjukpelaksanaan akreditasi perpustakaan, (Jakarta : Perpustakaan Nasional, 2014).hlm 2

${ }^{7}$ Sulistyo-Basuki. Pengantar Ilmu Perpustakaan. (Jakarta: Gramedia Pustaka Utama, 1993). Hlm 257.

8 Departemen Pendidikan Nasional RI. Perpustakaan Perguruan Tinggi: Buku Pedoman edisi ketiga. (Jakarta: Dirjen Dikti Kemendiknas RI, 2005). hlm 35 
Komponen Layanan memuat Elemen Penilaian Layanan, antara lain`:

a. Jam buka perpustakaan per hari dan per minggu

b. Sistem layanan, baik secara manual maupun secara elektronik.

c. Jenis layanan perpustakaan mencakup layanan minimal perpustakaan (bacaditempat, sirkulasi dan penelusuran informasi), maupun layanan tambahan(layanan photo copy, layanan bercerita, layanan khusus, layanan digital, dll).

d. Promosi perpustakaan menyangkut jenis dan jumlah promosi yang diadakanperpustakaan dalam jangka waktu tertentu.

e. Pendidikan pemakai dilakukan secara berkala disertai modul materi pendidikanpemakai.

f. Statistik layanan yang mencerminkan basil kegiatan layanan perpustakaan,meliputi: jumlah anggota, jumlah pengunjung dan jumlah buku yang dipinjamdalam kurun waktu tertentu.

Kualitas layanan akan sangat dipengaruhi oleh siapa yang melakukan layanan tersebut. Demikian juga kualitas layanan perpustakaan akan sangat dipengaruhi oleh kualitas pustakawannya. Jasa pustakawan di perguruan tinggi akan mempunyai peran yang berbeda dengan jasa pustakawan di perpustakaan sekolah atau perpustakaan umum.

\section{Gambar1. Jasa Pustakawan di Perguruan Tinggi}

Pengajar

Pustakawan

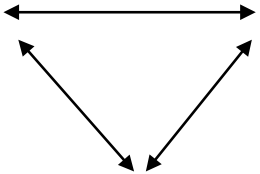

Mahasiswa

Sumber: Sulistyo-Basuki ${ }^{10}$

${ }^{9}$ Muh.SyarifBando dkk. Petunjukpelaksanaan akreditasiperpustakaan, (Jakarta : Perpustakaan Nasional, 2014).hlm 3

${ }^{10}$ Sulistyo-Basuki. Pengantar Ilmu Perpustakaan. Jakarta: Gramedia 
Gambar diatas menunjukkan bagaimana layanan pustakawan perguruan tinggi sangat berkaitan erat dengan keperluan informasi mahasiswa dan dosen.

\section{Analisis Penilaian Layanan}

Penelitian ini menggunakan standar akreditasi perpustakaan perguruan tinggi dari Perputakaan Nasional RI. Hasil penelitian dipaparkan sebagai berikut:

Tabel1. Komponen dan Indikator Kunci Akreditasi Perpustakaan Perguruan Tinggi:

\begin{tabular}{llcc}
\hline NO & \multicolumn{1}{c}{ KOMPONEN } & $\begin{array}{c}\text { JUMLAH INDIKATOR } \\
\text { KUNCI }\end{array}$ & BOBOT \\
\hline 1 & Layanan & 12 & 20 \\
\hline 2 & Kerja sama & 2 & 5 \\
\hline 3 & Koleksi & 12 & 15 \\
\hline \multirow{2}{*}{4} & Pengorganisasian Bahan & 3 & 10 \\
& Perpustakaan & & 15 \\
\hline 5 & Sumber Daya Manusia & 10 & 10 \\
\hline 6 & Gedung/ruang, Sarana & 33 & 10 \\
\hline 7 & Prasarana & 3 & 10 \\
\hline 8 & Manggaran & 4 & 5 \\
\hline 9 & Perawatan Koleksi & 3 & $\mathbf{1 0 0 \%}$ \\
\hline
\end{tabular}

Layanan Perpustakaan Purwokerto, dengan aspek layanan:

a. Jam buka perpustakaan perhari.

Sesuai buku panduan perpustakaan, Perpustakaan IAIN Purwokerto ${ }^{11}$ buka setiap hari kerja, Senin- Sabtu dengan jam layanan sebagai berikut:

Pustaka Utama, 1993. Hlm 51.

${ }^{11}$ Perpustakaan IAIN Purwokerto. Buku Panduan Perpustakaan 20162017. Purwokerto: Perpustakaan IAIN Purwokerto, 2016. hlm 16 
Senin- Jum'at : $08.00-15.30$ WIB (Jum'at s.d 16.00 WIB)

Sabtu $\quad: 09.00-14.30 \mathrm{WIB}$

adapun istirahat layanan

Senin-Kamis : $11.45-12.45$ WIB

Jumat $\quad: 10.30-13.00$ WIB

Dari keterangan tersebut diatas, dapat diketahui rata-rata jam buka perpustakaan 6,5 jam perhari.

b. Jam buka perpustakaan perminggu

Jam layanan perpustakaan perminggunya dapat diketahui dengan rincian sebagai berikut:

Senin - Kamis $\quad: 6,5$ jam X $4=26$ jam

Jumat : $\quad=5,5$ jam

Sabtu : $\quad=6$ jam

Jumlah $\quad=37,5$ jam

c. Sistem peminjaman buku

Sistem peminjaman buku menggunakan system otomasi dan manual. Sistem otomasi digunakan untuk peminjaman normal kepada semua anggota perpustakaan. Yang dimaksud peminjaman normal disini adalah peminjaman yang dapat dilayani langsung oleh petugas bagian sirkulasi.

Sistem manual digunakan untuk peminjaman yang tidak bisa dilakukan dalam sistem otomasi, misalnya ketika ada peminjaman buku Civic Education untuk satu kelas saat perkualiahan berlangsung, dan langsung dikembalikan setelah perkuliahan selesai. Peminjaman manual ini ditransaksikan oleh mahasiswa wakil dari kelas tersebut yang membawa surat keterangan dari dosen pengampu. Selain itu peminjaman kamus Al-Munawwir saat perkuliahan bahasa Arab berlangsung dapat dipinjam dengan cara yang sama. Peminjaman manual ini melalui bagian administrasi terlebih dahulu.

d. Persentase jumlah mahasiswa yang menjadi anggota perpustakaan Tahun Pelajaran 2016/2017 
Tabel2. Jumlah Mahasiswa yang Menjadi Anggota Perpustakaan

\begin{tabular}{ccc}
\hline Jenjang & Jumlah Mahasiswa & $\begin{array}{c}\text { Jumlah Yang Menjadi Anggota } \\
\text { Perpustakaan }\end{array}$ \\
\hline S1 & 6.791 & 4.542 \\
\hline S2 & 447 & 37 \\
\hline Jml & 7.268 & 4.580 \\
\hline
\end{tabular}

Persentase jumlah mahasiswa yang menjadi anggota perpustakaan lebih dari 63,02\%.

Menurut data dari bagian akademik dan kemahasiswaan (Mikwa) IAIN Purwokerto tanggal 23 September 2016 bahwa jumlah mahasiswa yang aktif adalah 7.268 orang, dengan rincian mahasiswa s1 6.791 orang dan mahasiswa s2 477 orang.

Adapun yang menjadi anggota perpustakaan menurut data ${ }^{12}$ berjumlah 4.580 orang dengan rincian mahasiswa s1 4.542 orang dan mahasiswa s2 7 orang.

Sehingga $4.580: 7.268$ X $100 \%=63,02 \%$

e. Persentase jumlah dosen dan tenaga kependidikan yang menjadi anggota perpustakaan.

Tabel3. Jumlah dosen dan Tenaga Kependidikan yang Menjadi Anggota Perpustakaan

\begin{tabular}{ccc}
\hline Jenis & Jumlah & $\begin{array}{c}\text { Jml Yg Menjadi Anggota } \\
\text { Perpustakaan }\end{array}$ \\
\hline Dosen PNS & 134 & 77 \\
\hline Dosen NPNS & 50 & 17 \\
\hline Tendik PNS & 73 & 94 \\
\hline Tendik Kontrak & 72 & 94 \\
\hline Jml & 329 & \\
\hline
\end{tabular}

Persentase jumlah dosen dan tenaga kependidikan yang menjadi anggota perpustakaan masih sangat kecil yaitu $28,57 \%$.

Menurut data dari bendahara IAIN Purwokerto tanggal 23 September 2016 bahwa jumlah dosen PNS dan NPNS

${ }^{12}$ Database Perpustakaan IAIN Purwokerto diunduh 23 September 2016 
berjumlah 184 orang, sedangkan tenaga kependidikan PNS dan kontrak berjumlah 145 orang.

Adapun yang menjadi anggota perpustakaan menurut data $^{13}$ berjumlah 94 orang dengan rincian dosen 77 orang dan tenaga kependidikan 17 orang.

Sehingga $94: 329$ X $100 \%=28,57 \%$

f. Jumlah rata-rata buku yang dipinjam perbulan dalam satu tahun.

Menurut data dalam database otomasi perpustakaan IAIN Purwokerto, jumlah rata-rata buku yang dipinjam perbulan adalah 3540 judul, yaitu kurang dari 4.501 judul.

g. Jenis promosi yang pernah dilaksanakan per tahun.

Adapun jenis promosi yang biasa dilaksanakan secara rutin per tahunnya terdiri dari: display buku baru dan orientasi (pendidikan pemakai). Dengan demikian, perpustakaan IAIN Purwokerto menggunakan dua jenis promosi.

h. Jumlah promosi perpustakaan pertahun.

Senada dengan jenis promosi yang dilakukan diatas, jumlah promosi yang dilakukan $=1-2$ kali pertahun, yaitu display buku baru setiap pengadaan buku baru dan promosi saat dilakukannya pendidikan pemakai perpustakaan bagi mahasiswa baru IAIN Purwokerto.

i. Pelayanan berbasis Teknologi Informasi dan Komunikasi (TIK).

Pelayanan yang diberikan oleh perpustakaan IAIN Purwokerto berbasis internet dan intranet (LAN).

Pelayanan internet antara lain:

- layanan multimedia yang dilakukan mandiri oleh pemustaka

- layanan penelusuran untuk keperluan membuat makalah komprehensif untuk rujukan berbahasa asing.

13 Database Perpustakaan IAIN Purwokerto diunduh 23 September 2016 
- layanan penelusuran untuk keperluan tugas dan penelitian.

Pelayanan intranet (LAN) antara lain:

- layanan OPAC (online public acces catalogue)

- layanan peminjaman mandiri

- layanan pengembalian dan perpanjangan peminjaman buku.

j. Literasi Informasi (pendidikan pemustaka, orientasi perpustakaan dll) pertahun.

Perpustakaan IAIN Purwokerto melaksanakan kegiatan literasi informasi berupa pendidikan calon pemakai perpustakaan kepada mahasiswa baru sebanyak 1 kali dalam setahun.

k. Otomasi perpustakaan.

Otomasi perpustakaan meliputi kegiatan penelusuran (OPAC), sirkulasi (peminjaman dan pengembalian/ perpanjangan pinjaman), dan keanggotaan (input data anggota, aktivasi keanggotaan, setting password anggota)

1. Layanan yang diberikan perpustakaan

Layanan yang diberikan perpustakaan IAIN Purwokerto meliputi layanan baca ditempat, sirkulasi, penelusuran informasi, bimbingan pemakai, dan fotokopi.

Tabel4. Hasil Survei Penilain Komponen Layanan di Perpustakaan IAIN Purwokerto

\begin{tabular}{|c|c|c|c|c|}
\hline No & Aspek Layanan & $\begin{array}{c}\text { Pilihan Jawaban } \\
\text { (pilih salah satu jawaban) }\end{array}$ & Nilai & $\begin{array}{l}\text { Total } \\
\text { Nilai }\end{array}$ \\
\hline 1. & $\begin{array}{l}\text { Jam buka } \\
\text { perpustakaan } \\
\text { per hari } \\
\text { Jawaban c }\end{array}$ & $\begin{array}{l}\text { a. } \quad \text { Lebih dari } 10 \text { jam per hari } \\
\text { b. } 9 \text { - } 10 \text { jam per hari } \\
\text { c. } 6 \text { - } 8 \text { jam per hari } \\
\text { d. } \quad 4 \text { - } 5 \text { jam per hari } \\
\text { e. } \quad \text { Kurang dari } 5 \text { jam per hari }\end{array}$ & 3 & 3 \\
\hline
\end{tabular}




\begin{tabular}{|c|c|c|c|c|}
\hline 2. & $\begin{array}{l}\text { Jam buka } \\
\text { perpustakaan } \\
\text { per minggu } \\
\text { Jawaban c }\end{array}$ & $\begin{array}{ll}\text { a. } & \text { Lebih dari } 48 \text { jam per } \\
\text { minggu } \\
\text { b. } 42-48 \text { jam per minggu } \\
\text { c. } 36-41 \text { jam per minggu } \\
\text { d. } 12-35 \text { jam per minggu } \\
\text { e. } \quad \text { Kurang dari } 12 \text { jam per } \\
\text { minggu }\end{array}$ & 3 & 6 \\
\hline 3. & $\begin{array}{l}\text { Sistem } \\
\text { peminjaman } \\
\text { buku } \\
\text { Jawaban a }\end{array}$ & $\begin{array}{l}\text { a. Sistem otomasi dan } \\
\text { manual } \\
\text { b. Sistem otomasi } \\
\text { c. Manual dengan } \\
\text { menggunakan sistem } \\
\text { kartu/brown } \\
\text { d. Manual dengan sistem } \\
\text { buku besar atau cara } \\
\text { lainnya } \\
\text { e. Tidak ada sistem yang } \\
\text { diterapkan }\end{array}$ & 5 & 11 \\
\hline 4. & $\begin{array}{l}\text { Persentase } \\
\text { jumlah } \\
\text { mahasiswa } \\
\text { yang menjadi } \\
\text { anggota } \\
\text { perpustakaan } \\
\text { Jawaban b }\end{array}$ & $\begin{array}{l}\text { a. } \quad \text { Lebih dari } 80 \% \\
\text { b. } \quad 61 \%-80 \% \\
\text { c. } 51 \%-60 \% \\
\text { d. } 21 \%-50 \% \\
\text { e. kurang dari } 20 \%\end{array}$ & 4 & 15 \\
\hline 5. & $\begin{array}{l}\text { Persentase } \\
\text { jumlah dosen } \\
\text { dan tenaga } \\
\text { kependidikan } \\
\text { yang menjadi } \\
\text { anggota } \\
\text { perpustakaan } \\
\text { Jawaban d }\end{array}$ & $\begin{array}{ll}\text { a. } & \text { Lebih dari } 80 \% \\
\text { b. } & 61 \%-80 \% \\
\text { c. } & 51 \%-60 \% \\
\text { d. } & 21 \%-50 \% \\
\text { e. } & \text { kurang dari } 20 \%\end{array}$ & 2 & 17 \\
\hline
\end{tabular}




\begin{tabular}{|c|c|c|c|c|}
\hline 6. & $\begin{array}{l}\text { Jumlah rata- } \\
\text { rata buku yang } \\
\text { dipinjam per } \\
\text { bulan dalam } \\
\text { satu tahun } \\
\text { Jawaban e }\end{array}$ & $\begin{array}{l}\text { a. } \quad \text { Lebih dari } 6.000 \text { judul } \\
\text { b. } \quad 5.501-6.000 \text { judul } \\
\text { c. } \quad 5.001-5.500 \text { judul } \\
\text { d. } \quad 4.501-5.000 \text { judul } \\
\text { e. } \quad \text { Kurang dari } 4.501 \text { judul }\end{array}$ & 1 & 18 \\
\hline 7. & $\begin{array}{l}\text { Jenis promosi } \\
\text { yang pernah } \\
\text { dilaksanakan } \\
\text { (misalnya } \\
\text { brosur, lomba, } \\
\text { pameran, } \\
\text { penyebaran } \\
\text { daftar buku } \\
\text { terbaru, display } \\
\text { buku baru, } \\
\text { orientasi, dll) } \\
\text { per-tahun } \\
\text { Jawaban d }\end{array}$ & $\begin{array}{ll}\text { a. } & \text { Lebih dari } 8 \text { jenis } \\
\text { b. } & 6-8 \text { jenis } \\
\text { c. } & 3-5 \text { jenis } \\
\text { d. } & 1-2 \text { jenis } \\
\text { e. } & \text { Belum pernah } \\
& \text { melaksanakan promosi }\end{array}$ & 2 & 20 \\
\hline 8. & $\begin{array}{l}\text { Jumlah promosi } \\
\text { perpustakaan } \\
\text { per tahun } \\
\text { Jawaban d }\end{array}$ & $\begin{array}{ll}\text { a. } & \text { Lebih dari } 8 \text { kali } \\
\text { b. } & 6-8 \text { kali } \\
\text { c. } & 3-5 \text { kali } \\
\text { d. } & 1-2 \text { kali } \\
\text { e. } & \text { Belum pernah } \\
& \text { melaksanakan promosi }\end{array}$ & 2 & 22 \\
\hline 9. & $\begin{array}{l}\text { Pelayanan } \\
\text { berbasis } \\
\text { Teknologi } \\
\text { Informasi dan } \\
\text { Komunikasi } \\
\text { (TIK) } \\
\text { Jawaban a }\end{array}$ & $\begin{array}{l}\text { a. internet dan intranet } \\
\text { b. internet } \\
\text { c. lokal (intranet) } \\
\text { d. Dalam persiapan } \\
\text { e. Tidak ada }\end{array}$ & 5 & 27 \\
\hline
\end{tabular}




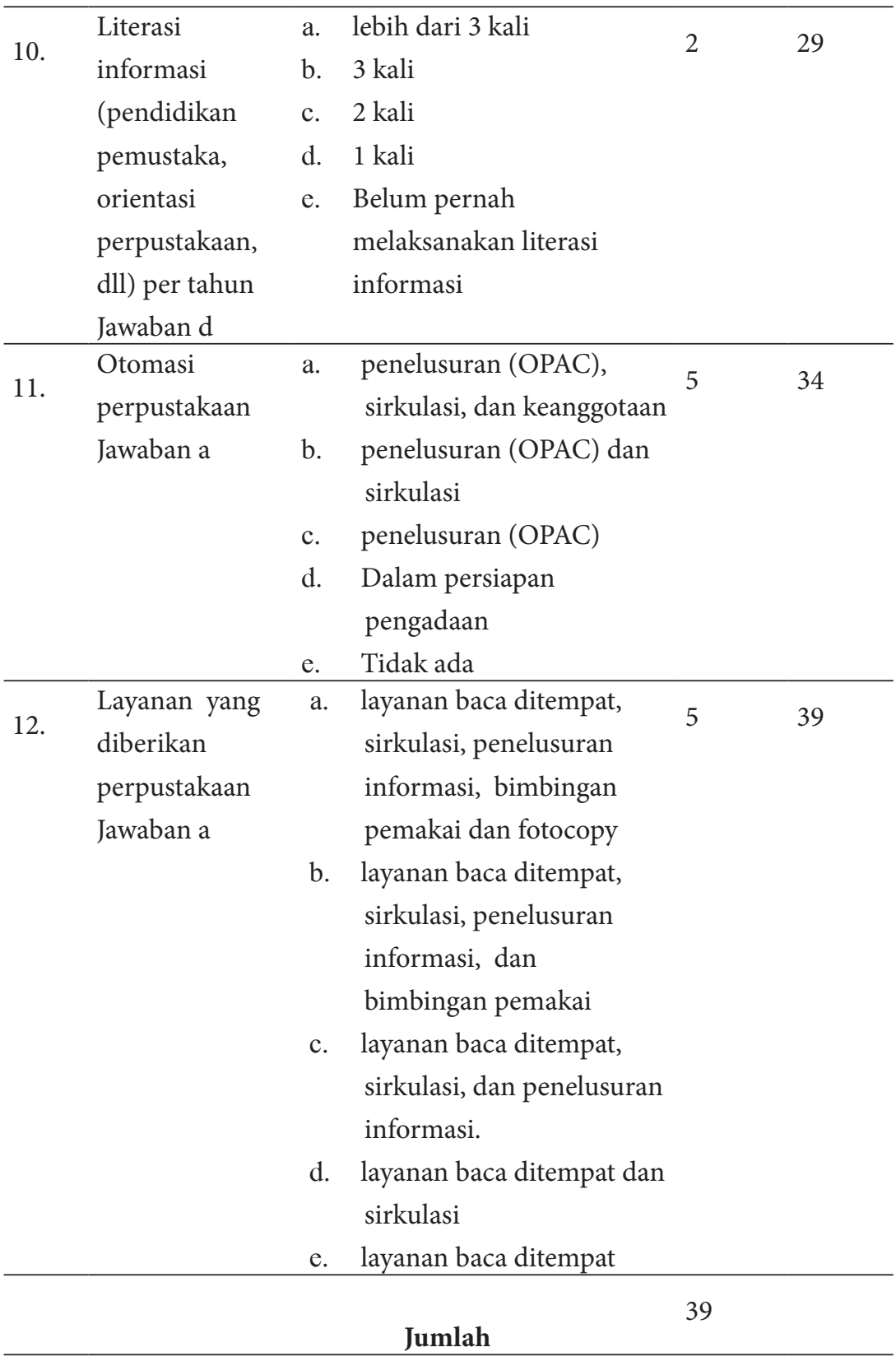

Tabel 5. Kelengkapan Bukti Fisik Aspek Layanan 


\begin{tabular}{|c|c|c|c|c|}
\hline \multirow[t]{2}{*}{ No. } & \multirow[t]{2}{*}{ Aspek Layanan } & \multirow[t]{2}{*}{ Bukti Fisik } & \multicolumn{2}{|c|}{ Keterangan } \\
\hline & & & Ada & Tidak \\
\hline 1. & $\begin{array}{l}\text { Jam buka } \\
\text { perpustakaan per hari }\end{array}$ & $\begin{array}{l}\text { Tata tertib perpustakaan } \\
\text { (memuat jam buka } \\
\text { perpustakaan) }\end{array}$ & & \\
\hline 2. & $\begin{array}{l}\text { Jam buka } \\
\text { perpustakaan per } \\
\text { minggu }\end{array}$ & $\begin{array}{l}\text { Tata tertib perpustakaan } \\
\text { (memuat jam buka } \\
\text { perpustakaan) }\end{array}$ & & \\
\hline 3. & $\begin{array}{l}\text { Sistem peminjaman } \\
\text { buku }\end{array}$ & - & & \\
\hline 4. & $\begin{array}{l}\text { Persentase jumlah } \\
\text { mahasiswa yang } \\
\text { menjadi anggota } \\
\text { perpustakaan }\end{array}$ & $\begin{array}{l}\text { Statistik anggota } \\
\text { perpustakaan } \\
\text { Statistik mahasiswa di } \\
\text { Perguruan Tinggi }\end{array}$ & & \\
\hline 5. & $\begin{array}{l}\text { Persentase jumlah } \\
\text { dosen dan tenaga } \\
\text { kependidikan yang } \\
\text { menjadi anggota }\end{array}$ & $\begin{array}{l}\text { Statistik anggota } \\
\text { perpustakaan } \\
\text { Statistik tenaga } \\
\text { kependidikan di } \\
\text { Perguruan Tinggi }\end{array}$ & & \\
\hline 6. & $\begin{array}{l}\text { Frekuensi rata-rata } \\
\text { anggota meminjam } \\
\text { buku/bulan }\end{array}$ & $\begin{array}{l}\text { Statistik peminjaman } \\
\text { dan buku yang dipinjam } \\
\text { per-bulan }\end{array}$ & & \\
\hline 7. & $\begin{array}{l}\text { Jenis promosi yang } \\
\text { pernah dilaksanakan } \\
\text { (bisa lebih dari satu) }\end{array}$ & $\begin{array}{l}\text { Laporan tahunan yang } \\
\text { memuat jenis promosi } \\
\text { per-tahun }\end{array}$ & & \\
\hline 8. & $\begin{array}{l}\text { Berapa kali } \\
\text { perpustakaan } \\
\text { melaksanakan } \\
\text { promosi per tahun }\end{array}$ & $\begin{array}{l}\text { Laporan tahunan } \\
\text { yang memuat jumlah } \\
\text { promosi per-tahun }\end{array}$ & & \\
\hline 9. & $\begin{array}{l}\text { Pelayanan berbasis } \\
\text { Teknologi Informasi } \\
\text { dan Komunikasi (TIK) }\end{array}$ & & & \\
\hline 10 & Literasi Informasi & $\begin{array}{l}\text { Laporan tahunan yang } \\
\text { memuat kegiatan } \\
\text { pendidikan literasi } \\
\text { informasi ( waktu } \\
\text { pelaksanaan, jumlah } \\
\text { peserta) }\end{array}$ & & \\
\hline
\end{tabular}


11. Otomasi perpustakaan -

12. Layanan yang

diberikan

perpustakaan

Jika nilai akhir diperoleh dari komponen layanan jumlah bobot masing-masing komponen. Skor dan predikat penilaian dapat dilihat pada tabel dibawah ini :

Tabel6. Predikat Penilaian

\begin{tabular}{cc}
\hline Nilai & Predikat Penilaian \\
\hline $91-100$ & Akreditasi A (Amat Baik) \\
\hline $76-90$ & Akreditasi B (Baik) \\
\hline $60-75$ & Akreditasi C (Cukup Baik) \\
\hline$<60$ & Belum terakreditasi \\
\hline
\end{tabular}

Berdasarkan tabel predikat di atas, jika perkiraan nilai total layanan Perpustakaan IAIN Purwokerto adalah 39, sementara total nilai komponen layanan adalah 60, maka $39: 60$ X 100\% = $65 \%$

Komponen layanan jika diakreditasi mendapat predikat $\mathrm{C}$ (Cukup Baik)

Jika Bobot Layanan dalam Akreditasi Perpustakaan adalah 20, maka komponen layanan di Perpustakaan IAIN Purwokerto didapatkan: 65:100 X 20 = 13

Komponen layanan mengumpulkan nilai 13 dari totalbobot nilai 100 untuk seluruh komponen akreditasi perpustakaan.

\section{Peluang/Potensi Untuk Menaikkan Nilai Akreditasi}

Undang undang perpustakaan mengatakan bahwa layanan perpustakaan dilakukan secara prima danberorientasi bagi kepentingan pemustaka ${ }^{14}$. Perpustakaan perguruan tinggi yang notabene pemustakanya adalah sivitas akademika, yang mana mempunyai keperluan informasi untuk menunjang tridharma perguruan tinggi tersebut. IAIN Purwokerto sudah seharusnya mempertimbangkan kepentingan (kebutuhan informasi)

${ }^{14}$ INDONESIA. Undang undang No.34 Tahun 2007. Pasal 14 Ayat 1. 
pemustaka baik mahasiswa S1, S2, dosen maupun tenaga kependidikan.

Melihat hasil penilaian diatas, ada beberapa hal yang dapat dilakukan untuk mendapatkan penilaian maksimal, antara lain:

a. Jam buka perpustakaan perhari.

Menurut Sulistyo Basuki ${ }^{15}$ terlalu singkat kalau jam buka perpustakaan perguruan tinggi hanya mengikuti jam kerja PNS yaitu buka pukul 08.00 - 16.00 (8 jam), padahal jika dikurangi istirahat siang hanya menjadi 7 jam saja. Menurut beliau juga rata-rata perpustakaan universitas buka 12 jam sehari. Hal ini biasanya terjadi di perguruan tinggi yang sudah maju/besar.

Perpustakaan IAIN Purwokerto dapat menambah jam buka sesuai waktu perkuliahan mahasiswa yang sampai malam hari pukul 21.00 WIB, dengan demikian jam buka perpustakaan bisa menjadi:

Senin- Jumat : $08.00-20.30$ WIB

Sabtu

$$
\text { : } 09.00-14.30 \text { WIB }
$$

adapun istirahat layanan

Senin-Kamis : 11.45 - 12.45 WIB

Jum' : $: 10.30-13.00$ WIB

Senin-Jumat : $18.00-18.30$ WIB (istirahat sholat maghrib)

Dari keterangan tersebut diatas, dapat kita tambahkan waktu rata-rata jam buka perpustakaan lebih dari 10 jam perhari.

Dengan penambahan jam buka perpustakaan sebagaimana di atas, maka berpotensi mendapat Nilai sebesar lima poin

b. Jam buka perpustakaan perminggu

Standar Nasional Perpustakaan menyebutkan bahwa layanan perminggu minimal 40 jam perminggu

${ }^{15}$ Sulistyo-Basuki,Akreditasi perpustakaan perguruan tinggi. https:// sulistyobasuki.wordpress.com/2013/10/27/akreditasi-perpustakaanperguruan-tinggi/ (diakses 9 September 2016) 
dan 5 hari kerja ${ }^{16}$. Namun sebenarnya sangat dianjurkan untuk dapat memberikan jam buka lebih banyak.

Jam layanan perpustakaan perminggunya dapat diketahui dengan rincian sebagai berikut:

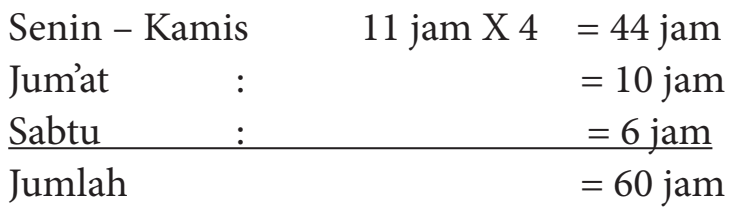

Dengan jam buka perpustakaan per minggu sebagaimana di atas, maka berpotensi mendapat nilai 5 .

c. Sistem peminjaman buku

Dengan sistem peminjaman buku sudah baik, maka berpotensi mendapatkan nilai lima.

d. Persentase jumlah mahasiswa yang menjadi anggota perpustakaan

Animo mahasiswa IAIN Purwokerto untuk menjadi anggota sangat tinggi. Namun persentase jumlah mahasiswa yang menjadi anggota perpustakaan baru 63\% , dapat ditingkatkan lagi menjadi diatas $80 \%$. Target ini sangat mungkin untuk dicapai, mengingat perpustakaan di IAIN Purwokerto terpusat.Dengan penambahan jumlah mahasiswa yang menjadi anggota perpustakaan berpotensi mendapat nilai 5

e. Persentase jumlah dosen dan tenaga kependidikan yang menjadi anggota perpustakaan

Masih diperlukan kerja keras dari perpustakaan IAIN Purwokerto agar dosen dan tenaga kependidikan yang menjadi anggota perpustakaan meningkat. Target yang masuk akal sekitar 51-60\% dosen dan tenaga kependidikan menjadi anggota.

Dengan demikian, berpotensi mendapat nilai 3

f. Jumlah rata-rata buku yang dipinjam perbulan dalam satu tahun.

${ }^{16}$ Muh.Syarif Bando. dkk. Standar nasional perpustakaan perguruan tinggi. Jakarta : Perpustakaan Nasional, 2013. hlm 6 
Masih sangat diperlukan upaya yang serius untuk menarik pemustaka untuk meminjam buku di perpustakaan IAIN Purwokerto. Ada beberapa alasan mengapa mahasiswa tidak meminjam buku (sumber data: hasil wawancara dengan mahasiswa saat memberikan pelayanan), antara lain:

1. Buku yang diperlukan tidak ada

2. Cukup membaca ditempat

3. Jatah pinjaman buku sudah maksimal (di iain purwokerto maksimal 5 buku)

Dengan demikian target logis yang dapat dipatok untuk unsur ini adalah tercapainya peminjaman buku perbulan 4501-5000 judul.

Target ini berpotensi mendapat nilai 2 .

g. Jenis promosi yang pernah dilaksanakan per tahun.

Kegiatan ini sangat berhubungan dengan poin sebelumnya, karena jika jenis promosi yang dilakukan lebih banyak, memungkinkan mendapatkan kunjungan yang lebih banyak dan pemustaka yang meminjampun akan lebih banyak. Jika kalangan sivitas akademika IAIN Purwokerto merasabahwa perpustakaan dapatmemenuhi kebutuhan informasinya, maka akan dengan sukarela mendaftarkan diri menjadi anggota perpustakaan.

Adapun jenis promosi yang memungkinkan untuk dilaksanakan dengan melihat sumberdaya yang ada antara lain:

1. Brosur

2. Penyelenggaraan berbagai even. Lomba-lomba, seperti lomba storytelling, penulisan artikel tentang perpustakaan, atau lomba kunjungan/peminjaman terbanyak dalam setahun.

3. Pameran buku, seperti yang sudah pernah dilaksanakan perpustakaan IAIN Purwokerto bekerjasama dengan cv (baru dilaksanakan 1 kali).

4. Penyebaran daftar buku terbaru, sangat mungkin dilaksanakan karena dengan melihat data 
penerimaan buku baru dalam buku inventaris kita dapat mengetahui dan menyebarkannya kepada pemustaka.

5. Bedah buku, sudah pernah dilaksanakan namun belum rutin. Kegiatan ini sangat mungkin untuk menjadi rutin.

6. Displaybukubaru, yangbiasanya hanya dilaksanakan pada pengadaan besar saja namun sebenarnya sangat mungkin dilaksanakan setiap ada pengadaan baik pengadaan melalui dipa, wakaf, hadiah, dll.

7. Orientasi/pendidikan pemakai, sudah rutin dilaksanakan setiap tahun kepada mahasiswa baru.

Peningkatan promosi tujuh jenis promosi per tahun sebagaiamana di atas akan berpengaruh menambah nilai 4 .

h. Jumlah promosi perpustakaan pertahun.

Masih sangat berhubungan dengan 2 poin sebelumnya karena banyaknya promosi dan banyaknya media yang dijalankan dalam promosi akan sangat berpengaruh terhadap jumlah kunjungan dan jumlah peminjaman buku. Jika promosi diatas (poin g) dilaksanakan 1 (satu) kali saja maka jumlah promosi pertahun menjadi 9 kali. Dengan demikian berpotensi mendapatkan nilai 4 .

i. Pelayanan berbasis Teknologi Informasi dan Komunikasi (TIK).

Pelayanan yang diberikan oleh perpustakaan IAIN Purwokerto berbasis internet dan intranet (LAN) sudah berlangsung, yang perlu ditingkatkan adalah kualitas layanannya. Dalam hal ini termasuk peralatan, seperti jumlah komputer yang memadai dan koneksi internet yang stabil.

j. Literasi Informasi (pendidikan pemustaka, orientasi perpustakaan dll) pertahun.

Ada beberapa kegiatan literasi informasi yang sangat mungkin untuk dilaksanakan, antara lain: 
1. Pendidikan pemakai perpustakaan (sudah rutin)

2. Pelatihan penelusuran hadis

3. Workshop penelusuran literature untuk penelitian (skripsi) bagi mahasiswa semester 7 keatas.

Denganpenambahanliterasiinformasisebagaimana di atas, berpotensi mendapat nilai 4 .

k. Otomasi perpustakaan.

Otomasi perpustakaan meliputi kegiatan penelusuran (OPAC), sirkulasi (peminjaman dan pengembalian/perpanjangan pinjaman), dankeanggotaan (input data anggota, aktivasi keanggotaan, setting password anggota). Ada yang perlu ditingkatkan adalah jumlah komputer untuk peminjaman mandiri. Dalam hal otomasi ini sudah mendapat nilai baik yaitu 5 .

1. Layanan yang diberikan perpustakaan

Layanan yang diberikan perpustakaan IAIN Purwokerto berupa: layanan baca ditempat, sirkulasi, penelusuran informasi, bimbingan pemakai, dan fotokopi. Dalam hal variasi jenis layanan ini sudah baik, sehingga mendapatkan nilai lima poin, yang perlu ditingkatkan adalah kualitas layanannya.

Dari paparan diatas dapat diketahui bahwa perpustakaan IAIN Purwokerto mempunyai potensi untuk mendapatkan nilai dari komponen layanan ini berjumlah 52.

\section{Simpulan}

Analisis terhadap layanan perpustakaan IAIN Purwokerto dalam artikel ini menunjukkan bahwa layanan perpustakaan memperoleh skor sebesar 39, atau 65\% dari total nilai layanan 60 . Perolehan nilai tersebut, membuka peluang ada beberapa aspek layanan yang berpotensi mendapatkan nilai lebih baik, antara lain: jam buka perpustakaan perhari, jam buka perpustakaan perminggu, persentase jumlah mahasiswa yang menjadi anggota, persentase dosen dan tenaga kependidikan yang menjadi anggota, 
rata-rata jumlah buku yang dipinjam, jenis dan jumlah promosi yang dilakukan dan kegiatan literasi informasi.

Adanya ketimpangan nilai layanan di perpustakaan IAIN Purwokerto antara layanan yang dilakukan saat ini dengan potensi layanan yang dapat dijalankan. Sebenarnya perpustakaan IAIN Purwokerto berpotensi untuk mendapatkan nilai layanan sebesar 52 dari hasil analisis layanan yang hasilnya 39. Sehingga ada selisih nilai $52-39=13$. Terdapat potensi nilai layanan yang berhubungan dengan kebijakan pimpinan perguruan tinggi yaitu jam buka layanan yang harus dimasukkan dalam peraturan perpustakaan. 


\section{DAFTAR PUSTAKA}

Bando, Syarif Muh. dkk. Petunjuk Pelaksanaan Akreditasi Perpustakaan, Jakarta : Perpustakaan Nasional, 2014.

Bando, Syarif Muh. dkk. Standar Nasional Perpustakaan Perguruan Tinggi. Jakarta : Perpustakaan Nasional, 2013.

Departemen Pendidikan Nasional RI. Perpustakaan Perguruan Tinggi: Buku Pedoman edisi ketiga. Jakarta: Dirjen Dikti Kemendiknas RI, 2005.

INDONESIA. Undang undang No.43 Tahun 2007 Tentang Perpustakaan.

Komarudin. Menyiapkan Akreditasi Perpustakaan http://library. stainkediri.ac.id/menyiapkan-akreditasi-perpustakaan/ (diakses 9 Agustus 2016)

Perpustakaan IAIN Purwokerto. Buku Panduan Perpustakaan 20162017, Purwokerto: Perpustakaan IAIN Purwokerto, 2016.

Riduwan. Belajar Mudah Penelitian Untuk Guru Karyawan Dan Peneliti Pemula, Bandung: Alfabeta, 2013.

Sulistyo-Basuki. Pengantar Ilmu Perpustakaan, Jakarta: Gramedia Pustaka Utama, 1993.

Sulistyo-Basuki,Akreditasi Perpustakaan Perguruan Tinggi. https:// sulistyobasuki.wordpress.com/2013/10/27/akreditasiperpustakaan-perguruan-tinggi/ (diakses 9 September 2016)

Suparmo, Paulus. Menggagas Kualitas Perpustakaan Perguruan Tinggi, VISI PUSTAKA, Vol. 14, No. 3, Desember 2012

Database Otomasi Perpustakaan IAIN Purwokerto, diunduh 21 dan 23 September 2016. 